\title{
Intraoperative Analgesic Regimen and Cholecystectomy: A Closer Look
}

\author{
Akira Umemura $^{\mathrm{a}, \mathrm{b}}$ Takayuki Suto $^{\mathrm{b}}$ Seika Nakamura ${ }^{\mathrm{b}}$ Hisataka Fujiwarab \\ Fumitaka Endo $^{\mathrm{b}}$ Hiroyuki Nitta $^{\mathrm{a}}$ Takeshi Takahara $^{\mathrm{a}}$ Akira Sasaki $^{\mathrm{a}}$ \\ ${ }^{a}$ Department of Surgery, Iwate Medical University, Morioka, Japan; ${ }^{b}$ Department of Surgery, Morioka Municipal \\ Hospital, Morioka, Japan
}

Dear Editor,

We appreciate the interest shown by Drs. Kendall MC and Castro-Alves LJ in our recent article "Comparison of SingleIncision Laparoscopic Cholecystectomy versus Needlescopic Cholecystectomy: A Single institutional Randomized Clinical Trial" published in Digestive Surgery [1]. They have raised three questions regarding the intraoperative analgesic regimen, type I error setting in statistical analyses, and patient-centered outcomes.

First, with regard to the standardized intraoperative analgesic regimen, all the enrolled patients underwent continuous intravenous infusion of remifentanil during surgery and $50 \mathrm{mg}$ of flubiprofen axetil was administrated at the end of surgery. We did not employ the ultrasound-guided

\section{References}

1 Umemura A, Suto T, Nakamura S, Fujiwara H, Endo F, Nitta H, Takahara T, Sasaki A: Comparison of single-incision laparoscopic cholecystectomy versus needlescopic cholecystectomy: a single institutional randomized clinical trial. Dig Surg 2018, Epub ahead of print.

2 Oh TK, Yim J, Kim J, Eom W, Lee SA, Park SC, Oh JH, Park JW, Park B, Kim nerve block [2] due to the long occupation of the operation room, and we did not employ any postoperative opioid administrations because overall analgesic use occurred only once during the hospital stay in the needlescopic cholecystectomy group. However, as we mentioned in the article, infiltration of the umbilical site with lidocaine or ropivacaine may reduce the postoperative wound pain in the single-incision laparoscopic cholecystectomy group owing to a larger incision compared to needlescopic cholecystectomy [3].

With regard to the query raised about the type I error setting in statistical analyses, we wish to state that type I error is called a error. We determined an a level of 0.05 ahead of time; hence, type I error was considered in all calculations and statistical analyses.

Finally, patient-centered outcomes usually evaluate the maintenance or improvement of the quality of life [4]. As they say, less pain or less incision is not necessarily connected to patients' quality of life and personal satisfaction; hence, further studies about patient-centered outcomes are warranted to clarify the true meaning of minimally invasive surgery.

\section{Disclosure Statement}

A.U., T.S., S.N., H.F., H.N., T.T., and A.S.: have no conflicts of interest or financial ties to disclose.

\section{KARGER}

(c) 2018 S. Karger AG, Basel
DH: Effects of preoperative ultrasoundguided transversus abdominis plane block on pain after laparoscopic surgery for colorectal cancer: a double-blind randomized controlled trial. Surg Endosc 2017;31: 127-134.

3 Philipp SR, Miedema BW, Thaler K: Singleincision laparoscopic cholecystectomy using conventional instruments: early experience in comparison with the gold standard. J Am Coll Surg 2009;209:632-637.

4 Zapf M, Denham W, Barrera E, Butt Z, Carbray J, Wang C, Linn J, Ujiki M: Patientcentered outcomes after laparoscopic cholecystectomy. Surg Endosc 2013;27:44914498. 